\title{
German regions compete for biotech funds
}

Munich. Germany last week announced that each of its 17 regions with established biotechnology communities has agreed to take part in a competition to see which of them has the best potential for technology transfer.

The competition is part of a campaign, launched last year by Jürgen Rüttgers, the research minister, to loosen bureaucratic controls on genetic engineering and also to reduce the public opposition that has held Germany far behind its European neighbours, particularly Britain and France.

The rules of the new competition require each region to demonstrate its potential for bringing biotechnological

\section{Fish industry backs seal of approval}

London. A leading conservation group has joined forces with one of the world's largest buyers of processed fish to launch an initiative aimed at promoting sustainable fishing. The move is intended by both sides as a bold attempt to employ the power of the market to curb overfishing.

The World Wide Fund for Nature (WWF) and Unilever, the Anglo-Dutch group, have embarked on a two-year consultation exercise aimed at creating a 'sustainably harvested' label for fish. Fisheries organizations, scientists and consumer groups will be encouraged to participate in a proposed independent Marine Stewardship Council, an elected body that will collectively set a standard for the label.

"There is enough scientific information that points to declining fish stocks. The problem is the lack of political will to stop overfishing," says Michael Sutton of WWF.

The initiative, which was launched on the day Unilever announced annual profits $£ 100$ million lower than expected, appears to challenge both national governments and the fishing industry. Governments keen to protect employment in the industry have so far failed to prevent overfishing. But if consumers insist on purchasing fish carrying the eco-label, hitherto reluctant suppliers may be forced to comply.

"We are open about the fact that we have a large fishing business," says Caroline Whitfield of Unilever, which has 20 per cent of the frozen fish market in the United Kingdom and the United States. "It is in our interests and those of our employees as well as consumers to make sure that there are enough fish in the sea."

The precise definitions of 'sustainably harvested fish' have yet to be worked out. But they are expected to apply to fish that have not been caught from depleted regions, that are not too young, and that have been caught using equipment that did not trap and kill large amounts of marine advances to the market with a minimum of bureaucracy. To be eligible, a region must have an established research base in biotechnology and a sufficient industrial muscle to exploit the results. It must also show that financial institutions, such as banks, are interested in providing funds.

Despite the considerable effort involved in preparing for the competition, the three winners will not be able to look forward to a generous financial prize. They will win only the right to compete with each other for a share of DM150 million in project money that the federal research ministry is hiving off from the DM175 million already available annually for biotechnology pro-

wildlife, known as the 'bycatch'.

All Unilever products - which include Bird's Eye in the United Kingdom and Gorton's in the United States - will do so by 2005 , according to Whitfield.

Unilever and WWF will jointly fund the consultation. But the cost of setting up and maintaining the council and of policing the label will be met by conservation groups, governments and foundations, not by industry, says Sutton.

The initiative has so far received a broadly favourable response from the UK Department of Agriculture, Fisheries and Food as well as the UK House of Lords

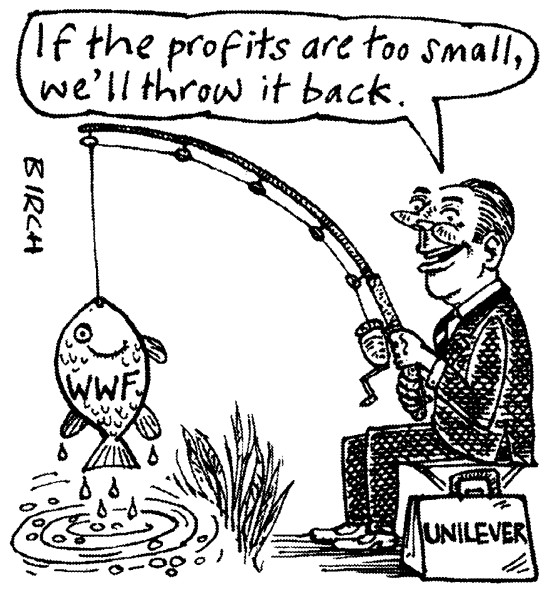

Select Committee on Science and Technology, which recently published a report calling for the setting up of broad-based fisheries management panels.

But the Earl of Selborne, a member of the committee, warns of potential "cynicism" from the fishing industry.

Trudy Johnston, a spokeswoman for the Scottish Fishermen's Federation, describes the scheme as "interesting", but says "this is the first we've heard of it, and it might have been better if WWF and Unilever had sought direct industry involvement at the outset".

Ehsan Masood jects. Indeed, there is no guarantee that the three 'strongest' regions will end up with more project money than they would have done without the competition.

But participants in the competition agree that their prime motivation is the prestige that will come from being identified as winners. According to Norbert Koenig, administrative director of the Society of Biotechnological Research in Braunschweig, Lower Saxony, such prestige will help to attract future investment.

A spokesman for the Bavarian economics ministry, which is coordinating Bavaria's application, adds that any region not taking part in the government's competition would be sending the "wrong political signals" to Bonn about its confidence in its biotechnology. In addition, he says, the federal research ministry has remained vague about possible future benefits for winners, and these could turn out to be more significant than the prize now being offered.

Detlev Ganten, director of the Max Delbrück Centre for Molecular Medicine in Berlin, says that it also signals the new recognition among federal politicians of the importance of biotechnology. "In Berlin it has stimulated a lot of discussion between banks, scientists and industry, and the development of many networks, that would not have happened without the competition", he says. In particular, he adds, it has made banks, which have little experience with biotechnology, more positive.

Rolf Kemler, director of the Max Planck Institute for Immunobiology in Freiburg, near the Swiss border, is also enthusiastic about the competition. But he fears that the losers may be seriously disadvantaged, both because there will be less money from the research ministry available to them, and because private finance would tend to concentrate on winning regions, as these would be seen as a lower investment risk.

The competition is being organized in two stages. In the first round, already completed, regions - in some cases as large as a whole Land, in others merely a pair of towns - have had to make a general presentation on how they could organize and finance particular research and development ideas.

Regions whose concepts are approved by the research ministry will receive half of the costs, up to a maximum of DM100,000 (US\$68,500) of preparing a full application, due by September. All are expected to receive this grant, and the winners are due to be announced in November. The strongest contenders appear to be Bavaria, Berlin-Brandenberg and LudwigshafenMannheim-Heidelberg, all of which already have strong and well-established biotechnology research bases.

Alison Abbott \& Quirin Schiermeir 